\title{
In vitro evaluation of mutant and wild strain of Trichoderma harzianum against soil borne plant pathogen
}

\author{
A.A. WALUNJ*1, P.B. ABHANG ${ }^{2}$ AND PRIYA JOHN²
}

${ }^{1}$ Department of Plant Pathology, College of Agriculture, Loni, AHMEDNAGAR (M.S.) INDIA

${ }^{2}$ Department of Plant Pathology, N. M. College of Agriculture, Navsari Agricultural University, NAVSARI (GUJARAT) INDIA

\section{ARITCLE INFO}

Received : 26.11 .2014

Revised : 11.02 .2015

Accepted : 28.02 .2015

KEY WORDS :

Mutant, Soil borne plant pathogens, $T$. harzianum, UV-irradiation

*Corresponding author: Email: akshaya17289@gmail.com

\begin{abstract}
Aqueous suspension of conidia of Trichoderma harzianum wild strain Th-W were placed on potato dextrose agar and expose to UV irradiation for 10,20,30, and $40 \mathrm{~min}$ at $20 \mathrm{~cm}$ distance from which four stable mutants of T. harzianum i.e., Th-M-1, Th-M-2, Th-M-3 and Th-M-4 were obtained as it differed considerably from wild strain (Th-W) for their morphological characteristics. In vitro evaluation of mutant and wild strain of T. harzianum against three soil borne plant pathogens, Fusarium oxysporum f.sp. lycopersici, Sclerotium rolfsii and Macrophomina phaseolina by dual culture method, revealed that mutant strains overgrew all the pathogenic fungi more rapidaly than the wild strain.
\end{abstract}

How to view point the article : Walunj, A.A., Abhang, P.B. and John, Priya (2015). In vitro evaluation of mutant and wild strain of Trichoderma harzianum against soil borne plant pathogen. Internat. J. Plant Protec., 8(1) : 108-111. 